\title{
Local Human Development in contexts of permanent crisis: Women's experiences in the Western Sahara ${ }^{I}$
}

\author{
María López Belloso and Irantzu Mendia Azkue \\ HEGOA Institute of Development and International Cooperation Studies (Bilbao) \\ University of the Basque Country \\ maria_lopez@ehu.es \\ iranmendia@yahoo.es
}

\section{ABSTRACT}

Sahrawi women are active agents in the social dynamics of the refugee camps, in which they have developed a number of coping strategies to overcome the hardships of a deteriorating humanitarian situation. Since the outbreak of the conflict and the forced settlement in Tindouf, Algeria, women have been responsible for the entire management of refugee camps, assuming leadership roles in many sectors of society. This paper highlights the Sahrawi women's contribution to the process of local human development in a context of protracted refuge such as the one in the Western Sahara. In addition to the enlargement of the refugee population's capacities in relation to material and physical assets, social and organizational abilities, and motivational strengths, one of the major achievements of Sahrawi women has been their own individual and collective process of empowerment within the camp life.

\section{KEYWORDS}

Western Sahara; gender; refugees; Local Human Development; capacities

\section{Introduction}

The humanitarian situation in the Western Sahara might be defined as a protracted emergency, in which Sahrawi population in the camps of Tindouf (Argelia) remains for more than 30 years now in a situation of permanent refuge. Life in refugee camps depends very much on international humanitarian aid and the willingness of donors to maintain it. However, despite this dependency several experiences carried out in Sahrawi refugee camps, lead in particular by women, allow us to identify ways in which coping mechanisms implemented from the onset of the refuge are having positive impacts in terms of Human Development.

When dealing with the chances for development in a situation of refuge, it makes little sense to adopt traditional approaches to development based exclusively on economic growth and income levels. Either does not seem to be appropriate to relay uniquely on a Basic Needs Approach in a context of permanent crisis in which the high dependence on international aid and the weariness of donors may have serious implications for the sustained fulfilment of refugees' 
basic needs. Besides, this approach falls to short when having to tackle the complex set of practical and strategic needs that emerge in a prolonged crisis.

In this paper, it is argued that a Local Human Development paradigm, based on the confluence of the Capabilities Approach and the Local Development Approach, is much more suitable for the analysis of development experiences in a protracted refugee situation. In particular, the case study presented is focused on the contributions that Sahrawi women have made to the development and enlargement of refugees' capacities, parallel to their own process of individual and collective empowerment.

On the one hand, the level of participation of women in the political, social and economic organization of camps can be considered as an indicator of the heterogeneity of Muslim societies in relation to the status of women. On the other hand, it is a clear manifestation that women are not just victims of conflict but above all active agents who develop a great number of strategies to resist and minimise its negative impacts. Therefore, the aim of this paper is to approach to the refuge experiences of Sahrawi women, as long as their strategies and coping mechanisms seem to have had much more visible and positive outcomes in terms of Human Development than other refugee situations.

\section{Framework: Local Human Development and protracted refugee situations}

Since the United Nations Development Programme (UNDP) coined the concept in 1990, Human Development has been assumed as a new approach to development based not exclusively on economic growth and incomes but on the process of enlarging people's choices (UNDP, 1990). This approach finds its theoretical core on Amartya Sen's work on capabilities and functionings, broadly known in development theory as the Capability Approach (CA). Sen defined Human Development as "the process of enlarging a person's functionings and capabilities to function, the range of things that a person could do and be in her life" (Sen, 1999).

According to the UNDP, capacity refers to "the ability of individuals, communities, institutions, organizations, social and political systems to use the natural, financial, political, social and human resources available to them for the definition and pursuit of sustainable development goals" (UNDP, 2002). The range of definitions and perspectives on this concept is wide among researchers and practitioners. Several authors after Amartya Sen's work have tried to be more specific and set a list of basic or core capabilities. For some, capacity remains as a human resource issue, which has to do with the development of skills and training at the individual level (Alsop \& Kurey, 2005). For many others, capacity goes beyond the usual training and technical assistance and they see it as the ability to deliver or implement better (Moore, 1995).

Even if UNDP's formulation contains a reference to both individual and collective aspects of the notion of capacity, when it comes to its measurement, the Human Development Index tends to focus only on individual capacities. Acknowledging the importance of this dimension, we argue that it is necessary to highlight the equal relevance of the collective dimension of the term. For the purpose of this paper, then, capacity will be also understood as the collective skills or aptitudes of an organisation or system to carry out a particular function or process. These 
two dimensions are well contained in Morgan's definition of capacity as "the emergent combination of attributes that enables a human system to create developmental value" (Morgan, 2006).

However, the notion of human development may only be framed and measured when applied in a specific context, which makes it necessary to adopt a Local Development approach. Local Development is defined as "the process and outcome of the complex interactions and actions of different stakeholders at the local level to promote human development" (UNDP, 2007). It takes a multi-sectoral focus on economic, political, social and environmental factors and it includes civil society organizations, local communities, local governments, private sector companies and national governments. Local Development ensures sustainability through local ownership and broad stakeholder participation; it promotes accountability and aims to empower the most marginalized or vulnerable groups. Surely, for their concerned efforts to be successful, all local actors involved in this process need to be capacitated to contribute to the improvement of their situation, which implies the need to generate processes of empowerment.

As it occurs with the concept of capacity, there are equally many different definitions of empowerment. However, the common element to all of them is the centrality of the idea of power. Given that power is a multidimensional concept, the notion of empowerment necessarily contains various different and inter-related aspects ${ }^{\mathrm{II}}$. Above all, empowerment is not only about the access to decision-making, but also about the processes that lead people to perceive themselves as capacitated and legitimated to occupy those decision-making spaces (Rowlands, 1995:161).

Within the humanitarian and development field, the concept of empowerment has become eventually the central object of academic research, practice and policy planning, especially in relation to gender issues. When applied to development, gender theory has highlighted that empowerment constitutes a bottom-up process, originated at the local, community level, rather that something that can be formulated from a top-down perspective. As a consequence, development or humanitarian international agencies could never empower people (be it women, refugees, indigenous people...), but it is always the population at the local level that develop strategies to empower themselves.

The accent, then, is put on human agency and the individual and collective capacities for social transformation, which has always been a main objective of feminism to be achieved through processes of gender consciousness and empowerment. From a gender perspective, the understanding of empowerment is above all linked to the collective organization or "power with", along with a strong promotion of ideas about the "power within". In fact, drawing mainly from the human rights and feminist perspectives, many definitions of empowerment contain the idea that a fundamental shift in perceptions, or "inner transformation", is essential to the formulation of choices. That is, women should be able to define self-interest and choice, and consider themselves as not only able but also entitled to make choices. Some authors, such as Naila Kabeer, go a step further and describe this process in terms of thinking outside the system and challenging the status quo (Kabeer, 2001). 
Finally, in the intersection of both Human Development and Local Development, the idea of Local Human Development emerges. Although this relatively recent term has been rarely used in contexts of refuge, it offers a useful framework from which to analyse the experiences of refugee population. Local Human Development in these contexts puts the accent on the process of enlargement of local actors' capacities to recover from the crisis, regain autonomy and a sustainable livelihood and set the basis for a longer-term development. Besides, the emphasis put on the most marginalized groups' empowerment turns to be especially relevant in the case of women, who have been traditionally portrayed in refugee and development studies as a 'vulnerable group' with no chances for their survival but to rely on international assistance.

Therefore, the assumption here is that a Local Human Development approach that takes into account the gender variable, allow us to account for the experiences of women not exclusively as victims (victims of gender based violence, refugees with no option, widows without any resources, community workers excluded from the main decision-making organizations, and so on), but as relevant actors in the (re)production of social reality. It is a framework from which women's collective action may be underlined, especially in times of crisis or hardship, given that it is precisely in the most complex and threatening situations when women develop resources, abilities and capacities to confront them.

In a refugee-generating situation, the first reaction of the international community is to ensure the survival of refugees, assisting them with emergency relief and humanitarian aid (provision of shelter, medical assistance, water and food). Aid is aimed at the provision of the most basic human needs and designed as a temporary response to crisis. In the cases where refugee camps are established, the main question that arises is how to guarantee that camps are able to provide refugees with favourable living conditions and, eventually, how to promote a longer-term development when the situation of refuge persists. More outstandingly, this should be the case of the so-called protracted refugee situations, defined by the United Nations High Commissioner for Refugees (UNHCR) as those in which "refugees find themselves in a long-lasting and intractable state of limbo. Their lives may not be at risk, but their basic rights and essential economic, social and psychological needs remain unfulfilled after years in exile. A refugee in this situation is often unable to break free from enforced reliance on external assistance" (UNHCR, 2006).

Over the 90's, an ongoing debate about how to plan a conceptual framework able to merge the different priorities of providing humanitarian aid to refugees went on. The varieties of additional support in refugee emergencies are often limited to current aid design (ODI, 2001), which is usually divided into development and emergency responses. However, recently there have been interesting attempts to prioritise some of the resources to drive self-sufficiency and productivity of refugees (Bakewell, 2002), and humanitarian actors have reviewed their policies for a more effective transition between emergency relief to development cooperation. In this direction, adopting a livelihood approach ${ }^{\mathrm{III}}$ is determinant for developing refugees' self-reliance, strengthening their productive capacity and promoting the basis for a longer-term selfsufficiency. Of course, this should be especially so in protracted refugee situations. As ACORD stated, "for refugees hosted in camps, the livelihood approach needs to be tailored to call atten- 
tion to the vulnerability of people exposed to constant threats of violence and subject to new forms of risk, such as natural disasters, poverty, social exclusion, lack of physical or intellectual capacities, or lack of protection" (ACORD, 1995).

The Sahrawi camps in Algeria are certainly a case of protracted refugee situation ${ }^{\mathrm{IV}}$, and a case in which the population has been for decades almost entirely dependent on international humanitarian aid. However, it is also a situation in which we may identify local efforts to overcome this enforced reliance on external assistance. In particular, as it will be highlighted, women's collective action to guarantee refugee's livelihoods and thus to reduce their vulnerabilities are at the centre of the promotion of self-sufficiency among Sahrawi refugee population.

\section{Case study: Women's experiences in the Sahrawi refugee camps}

\section{Historical context of the Western Sahara conflict}

The origins of the Western Sahara conflict date back to 1975 when Spain, the colonial power at the time, withdrew from the territory without implementing a referendum on self-determination, and thereby contravening various United Nations Resolutions (UN, 1960). The Front for the Liberation of Saguia el-Hamra and Rio de Oro (POLISARIO Front), which was created in 1973 to fight for the independence of the Sahrawi people from the Spanish colonial power, was then confronted with a bilateral invasion by Morocco and Mauritania, both signatories to the November $14^{\text {th }} 1975$ Madrid Tripartite Agreement with dictator Franco's crumbling government ${ }^{\mathrm{V}}$.

With the assistance of the POLISARIO Front, the majority of the Sahrawi people fled across the desert to Algeria, on the way suffering aerial attacks from Moroccan aircraft using white phosphorus and Napalm (Lippert, 1992). The POLISARIO Front proclaimed the establishment of the Sahrawi Arab Democratic Republic (SADR) in Bir Lehlu on February $27^{\text {th }}$ of 1976 and declared a National Liberation War, initially on Mauritania and later on Morocco, after the Mauritanian retreat in 1979. War continued until 1991, when a cease-fire was signed between the parties and the United Nations deployed a special mission in the area (MINURSO) to monitor the cease-fire agreement and to organize and conduct a referendum which would allow the people of the Western Sahara to decide their future status.

As a result of the conflict, more than half Sahrawi population (around 165.000 people) was forced to leave their country and settled in refugee camps near the Algerian town of Tindouf. Sahrawi refugees established in four big camps named wilayas ${ }^{\mathrm{VI}}$ : El Aaiun, Smara, Dajla and Auserd. Each wilaya was divided in several municipalities named dairas ${ }^{\mathrm{VII}}$ and, at the same time, each daira was divided into four neighbourhoods or group of haimas (tents). This structure facilitated the political and administrative organization of the POLISARIO Front and the SADR. On their part, those Sahrawi unable to join the exile to Tindouf (around 40.000 people) were trapped in the so-called "occupied territories"

Even if the cease-fire opened-up the chances for a referendum that would guarantee the right of the Sahrawi people to self-determination, it has never taken place to date. There have been several UN attempts, though unsuccessful due mainly to the unwillingness of Morocco to ac- 
cept the conditions for the celebration of the referendum. The peace process in the Western Sahara continues to be stagnated and there seem to be no new initiatives to move on. This situation is aggravated by the neglect on the part of the international community, an attitude that has turned this conflict into a "forgotten" one. The fact that is not a priority in the international agenda, compounded by progressive reductions in international aid ${ }^{\mathrm{IX}}$, has direct negative impacts on Sahrawi people, who confront practically on their own the adverse living conditions of the refuge.

\section{The gender dimension of the conflict}

Women are part of the Sahrawi National Liberation Movement from the time of its foundation. Only one year after the POLISARIO Front was formed, it promoted in 1974 the creation of the National Union of Sahrawi Women (NUSW) as a fundamental part of the structure of the Liberation Movement. The NUSW was born as a mass organization and assumed the representation of all women in the Sahrawi Arab Democratic Republic (SADR). Under the direction of a National Secretariat and an Executive Buro, the NUSW was structured at the local, regional and national level around four working areas: occupied territories and emigration, information and culture, political and professional training, and foreign affairs.

By means of the NUSW, women in the Western Sahara have historically pursued two main objectives: the fight for the independence of their people and the fight for their claims as women. This relationship between national liberation objectives and gender equity ones, which is a common feature of the majority of armed revolutionary processes, is very frequently characterised by the prioritization of the national liberation aspirations over specific demands about the subordination suffered by women (Turpin, 1999). This was the case, for instance, of the majority of national liberation movements in Central America, during which women were frequently asked to support first and foremost the liberation movement they participated in and postpone their gender claims until more favourable national conditions would allow tackling other allegedly "less important" issues (such as "women's problems"), with the usual risk that this postponement ended to be indefinite (Ibañez, 2001; Vázquez, 1997).

Moreover, in the case of Islamic countries, the link between national fight and gender has other nuances. Not only women's demands are pushed into the background but also, in certain countries, the nationalist discourse often tends to be a lot more restrictive (Juliano, 1998). The main message passed on to women is that they should solely support the liberation movement, given that gender claims are supposed to be contrary to the popular tradition and could even break the unity of the national fight ${ }^{\mathrm{x}}$.

However, the Sahrawi Liberation Movement offers a kind of a "third way" in which nationalist revolutionary thinking can be related to activism for gender equity. In this case, gender claims are indeed an important part of the specific tradition that Sahrawi people want to maintain, and one of the main axis of the new society that they are building in exile. For Sahrawi people, respect and consideration of women and their demands constitute precisely a feature that differentiates them from Morocco. Consequently, all efforts towards gender equity are more easily perceived as part of their ethnic identity and also part of the basis for their independence struggle. 
In order to understand the particularity of Sahrawi women and their position in the refugee camps, it is necessary to take into account the traditional construction of gender roles in the Western Sahara. In fact, the extended participation of Sahrawi women in society and the social recognition enjoyed by them cannot be only attributed to their recent historical experience in the SADR, but it is something that comes along with the history of the Sahrawi people, that is, the history of their life as nomads, in which women were considered, respected and contributed to society the same way other members did.

Given that Sahrawi women are inhabitants of a geographical area that constitutes the bridge between two different historical and socio-cultural realities (North Africa and Sub-Saharan Africa), and given that they integrated both the Arab and the Berber ethnic tradition, they have developed adaptation strategies of diverse cultural contents which differentiate them from other Muslim women. The beduine tradition (Arab nomads) always assigned a decisive role to women in the management of assets and in the functioning of nomad communities. In ancient times, almost all desert nomads were matrilineal and matrilocal communities ${ }^{\mathrm{XI}}$. These characteristics of family organization allowed women to maintain certain movement autonomy reflected, for instance, in the possibility to receive visits both feminine and masculine even if they were home alone, and coming out and in their home on their will, without being dependant on their husband's permission. These customs were certainly unthinkable to other Muslim peoples of the area. Nowadays, they have maintained important elements of those traditional values favourable to women, such as the lack of sex segregation (women and men share public and private spaces), women's autonomy, the lack of utilisation of the veil and the social sanctioning of violence against women.

Added to the influence of cultural and traditional aspects in the status of Sahrawi women, the relevance of their involvement and participation in the Sahrawi National Liberation Movement is another element that helps explaining the nature of their experiences in the refugee camps.

In the Western Sahara, the prominence gained by women since the outbreak of the conflict is very clear. The independence war between the POLISARIO Front and Morocco conveyed the militarisation of men and the plight of mostly women and children. In the absence of men ${ }^{\mathrm{XII}}$, Sahrawi women assumed the responsibility to organise and manage entirely the life in the refugee camps, which accounted for around 165.000 people and constituted almost a kind of a

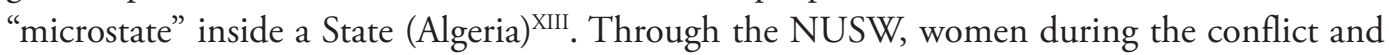
after 1991 planned and organised the functioning of all sectors in the camps: they were in charge of different working committees established in each neighbourhood, such as education and training, health, food distribution and justice and social issues. Given the relevance of Sahrawi women's role during the past three decades, the next section will deal with the contents of their contributions to the human development process in the refugee camps.

The following information is based on field work conducted during two visits to the refugee camps in Tindouf, the first one in December 2007 and the second one in April 2008. For the case, qualitative research methods were applied, considering these are the most appropriate 
tools for the study of social processes (capacity enlargement, empowerment) whose complexity is beyond the faculty of explanation of the merely quantitative. Indeed, qualitative research allows a better understanding of the dynamics operating in social phenomena; is interested in learning about the human experience; and studies the quality of activities, relationships, material means or instruments in a particular situation or context.

During the field visits, semi-structured interviews were carried out with representatives of the POLISARIO Front and the National Union of Sahrawi Women, following a purposive sampling technique. Besides, information was also gathered though various focus groups, which were composed of women workers and volunteers at the Women's Houses of the four wilayas as well as the " $27^{\text {th }}$ of February" camp. All focal groups were participated by the director of each Women's House and the people responsible for various areas covered by these centres (health, literacy and information), as well as women representatives of the Offices of Regional Development and Microcredit.

\section{Human development strategies promoted by Sahrawi women}

As above mentioned, the notions of capacity and vulnerability are central to the human development approach. On the one hand, capacities determine a person's or social group's ability to confront a crisis and recover from it; on the other hand, vulnerabilities refer to those factors that weaken people's capacities to cope with the effects of the crisis. Adopting a capacities and vulnerabilities approach is not only useful to highlight the strengths and weaknesses of refugee population, but it also adds a development orientation to humanitarian aid. Sahrawi women have never acted as a vulnerable group dependent on external emergency aid; on the contrary, these women assumed right from the start of the refuge that they had a role to play in the economic and social long-term development of their people, and this objective could only be achieved through the enlargement of their capacities.

Therefore, in order to structure Sahrawi women's contributions to human development in the camps, the Capacities and Vulnerabilities Framework originally developed by Anderson and Woodrow (1989) may be an adequate methodological resource. Capacities, in this case, are divided in three groups: capacities related to people's material and physical assets; social and organizational capacities; and motivational capacities, referring to people's attitudinal or psychological strengths.

\section{Development of material capacities}

The main source of material assets available to Sahrawi refugees comes from the international humanitarian aid. Since refugee camps were established in Algeria, women assumed and have maintained the responsibility of the equal distribution of emergency aid among population. However, conscious of the fact that only by means of productive activities could refugees regain economic autonomy and guarantee their livelihoods, women have been fundamental promoters of the implementation of income-generating activities in the camps.

During this decade, in those cases in which the international community has supported income-generating programs in refugee camps, these have been developed usually in two ways. 
The most common system consists of a grant-based program, and a less used one is based on micro-finance, in which a line of credit is provided for beneficiaries to start small businesses. According to some practitioners, loans are better forms of aid because they break the dependency cycle associated with humanitarian aid by encouraging a responsible use of resources. Consequently, micro-finance programs have played an increasingly important role in the drive towards economic self-reliance of refugees. They are meant to provide sustainable livelihoods, to revive local economy, and provide a boots to household economy in order to create the means for development (Cavaglieri, 2005).

Following the same purpose, Sahrawi women have recently developed a pioneer Women's Cooperatives Programme. This programme emerges out of their will to strengthen local economic and productive structures, in particular by the promotion of small initiatives of productive cooperatives among women. It contains a line of micro-credits concession as to finance different productive experiences. By means of cooperatives, women aim not only at obtaining economic benefits for them and their families, but also to increase the level of empowerment needed to improve their status within family and community relations. To mention just a few of the small business created through this programme, women are in charge of cooperatives focused on melf $a^{X V}$ dyeing, catering services, hairdressers and small farming, among others. Through the promotion of these economic activities, women intend to improve refugee's capacities and strategies to make a living and achieve income security, that is, ensure their livelihoods.

\section{Development of social and organizational capacities}

The moment Sahrawi population settled in refugee camps in Algeria, 90\% of the population was illiterate. Education provided by the Spanish colony came late and was exclusively focused on training men to become the workforce in the exploitation of natural resources (Cistero \& Freixes, 1987). Therefore, in relation to social capacities, the most outstanding contribution of Sahrawi women to human development in refugee camps has been the promotion of universal education and training.

From the early stage of the refuge, Sahrawi women gave priority to literacy campaigns and the organization of the whole education system. They organised themselves to teach children to read and write in provisional schools in the haimas, and by 1980 they had structured what nowadays constitutes the Sahrawi education system. The system is mixed and compulsory, and it covers kinder garden, first and secondary schooling. As for university education, the POLISARIO Front has several collaboration agreements with countries such as Argelia, Libia, Cuba, Siria and Spain, by which young people -both women and men- study their degrees abroad and then return back to the camps to be incorporated in different community services: schools, health centres or hospitals, administration, and so on.

It is worth underlying that, as a result of women's leadership in the organisation of the education infrastructure, the " $27^{\text {th }}$ of February" camp was created to host the biggest education centre for women in exile, which offers a wide range of training opportunities. Even if it was originally founded for girls and students who attended the different schools located there, 
eventually the " $27^{\text {th }}$ of February" education complex has turned into a fifth camp in which many women and their children live on a permanent basis. Students are selected by daira committees upon consideration of the particular skills needed by each daira. The school originally gave training in nursing, sewing, leather work and carpert making, and nowadays it also includes subjects such as teaching or computing. Each year there are around 300 women who arrive with their families and their haimas to the school, to follow a ten month lasting course from September onwards.

Apart from their role in the development of individual and social capacities of refugees through education programmes, Sahrawi women have also starred one of the most interesting experiences directed to prepare the population for a future return to an independent state: the promotion of training programmes for technical personnel of the Sahrawi administration. In fact, the NUSW was the first organization, along with personnel from some ministries of the SADR, to participate in these programmes, which were initiated in 1998. The final purpose is the training of technical cadres and the strengthening of local institutions.

Alongside with education and training, health was another area prioritised by Sahrawi women as to promote human development. Settlement of refugees in camps was done in really harsh conditions ${ }^{\mathrm{XV}}$, which lead to high rates of mortality due to different epidemics and childhood malnutrition. Women helped reversing this situation by establishing and organising in the camps a health infrastructure based on both healthcare and preventive medicine. This infrastructure is composed by small health centres at the municipal level (one per daira) as well as provincial centres or hospitals (one per wilaya) and two general hospitals in Rabuni ${ }^{\mathrm{XVI}}$.

Counting on social networks, the NUSW has also created special healthcare teams to respond to the needs of those sectors of the population who are exposed to greater risks, such as pregnant women, children and convalescents. On the one hand, there are mother and children monitoring groups (three to four women per quarter) who report about the situation of pregnant and nurturing women, as well as feeding babies, and assure the compliance with the immunisation schedule. On the other hand, there is also a group of people (10 women monitored by a nurse) attached to each health centre, who are responsible for visiting the sick in their haima and for taking the necessary medication control. Finally, the NUSW manages a care unit for disabled people in Njaila, although it has great limitations, such as few and often outdated resources or little training in rehabilitation. This unit, as well as much of the rest of the health system, remains highly dependant on international aid; the majority of medical supplies are part of the emergency aid and major interventions have to be performed either abroad or through visits of foreign professionals into the camps.

Added to the preventive and healthcare efforts, Sahrawi women have paid particular attention to training in this sector. In particular, the " $27^{\text {th }}$ of February" school for women has served as the platform for the formation of the health cadres of the refugee camps. Here the NUWS has trained nurses and laboratory and pharmacy technicians, while the training of medical personnel had to be carried out in other countries, mainly in Cuba. 
Finally, women are in charge of the committees related to justice and social affairs. On the basis of the SADR's legislation, these committees have the responsibility to intervene in all issues related to civil society. These issues include marriages, divorces, deaths and all kind of disputes among refugees. In reference to divorces, it is important to note that, contrary to the law in other Arab cultures, Sahrawi women may take the initiative on their own and the husband is usually the one obliged to abandon the home. In this respect, a great advancement in the social organisation of the refugee camps was the creation in 2002 of a State Secretariat for Social Affairs and the Emancipation of Women. The existence of this body has allowed the NUSW an even wider dedication to gender issues as the main criteria for the activities organised with women. This newly created institution is also promoting the incorporation of more women to the work of the NUSW, both refugee women and other women from international associations and networks who share the objectives of the empowerment of Sahrawi women.

\section{Development of motivational capacities}

For Sahrawi women, empowerment in terms of "power within" is the basis for the enhancement and consolidation of their autonomy, and it improves their presence and participation in the social, political and economic decision-making spaces of their community Thus, women's empowerment is considered as essential for the development of the Sahrawi people.

One of most relevant means by which the NUSW is working towards the empowerment of Sahrawi women are the so-called Women's Houses. The precedents of these centres for women were the "Workshops for the promotion of women" organized in every neighbourhood and daira to allow women to participate in all kind of courses, seminars and talks. The dynamisation of these workshops was only possible thanks to the wide involvement of women as leaders, educators and monitors, which guaranteed the orientation and analysis of the situation of women in every organized activity. In a short period of time, this project expanded so much that it exceeded the expectations and resources available. As a result, women planned the creation of the first Women's House in the wilaya of Smara. With external aid, soon this experience was reproduced in the rest of the wilayas.

Women's Houses are considered by the NUSW as a space for gathering and collaboration among women; for information and training, and for the impulse and coordination of services and activities which aim at the elimination of any kind of obstacles for women's emancipation (El Mehdi, 2006). To date, Women's Houses are a fundamental resource for the enlargement of women's motivational capacities, understood as their attitudinal and psychological strengths.

\section{Final remarks: Limitations and uncertainties of the future}

Despite improvements in terms of human development, Sahrawi refugees encounter many limitations that threaten to undermine their costly reached achievements. Above all, the longlasting exposure to exile and the continued neglect by the international community is having a serious impact on Sahrawi society in the camps.

Firstly, the fatigue and frustration of large sections of the refugee population is having negative effects on the implementation of community organization tasks. For instance, it has been 
identified a decline in the level of motivation of school teachers and medical personnel of the healthcare centres. At the same time, many young people who benefit from the SADR's education programmes and have the chance to obtain a university degree abroad, upon their return they find great difficulties to put into practice their acquired knowledge. The lack of job opportunities increases the level of frustration in this important segment of the population.

Another phenomenon also occurring inside the camps is the entry of foreign currency sent home by Sahrawi emigrants working abroad or families who host Sahrawi children through the programme "Holidays in Peace"XVII. This influx of money, coupled with that coming from some recently started small businesses, is beginning to generate social inequality, which if not managed properly could lead to social conflict in the short and medium term.

Besides, prolonged exposure to humanitarian aid programs is perpetuating the habit of receiving almost everything the population need to survive, which has a direct impact on the motivations to develop productive capacities in the camps. Over the decades, international intervention has been mainly focused on covering basic needs of refugees, concentrating almost exclusively on primary well-being aspects. As a consequence, a "culture of dependence" on externally provided aid has developed, which implies not only that refugees give increasingly less value to aid received but also that the capacities and autonomy of refugees are negatively affected. This situation is being detected by several aid donors, such as the Spanish Agency of Development Cooperation (AECID) and $\mathrm{ECHO}^{\mathrm{XVIII}}$, who have timidly begun to work on mechanisms for a better aid coordination and for the introduction of development programs focused on local production.

However, aid dependency in the camps has been constantly confronted by Sahrawi women. They have become active agents in the promotion of livelihood strategies, based on the conviction that the high vulnerability of refugee population cannot be reduced by humanitarian aid exclusively (food supplies and medicine) if not accompanied by the promotion of processes of autonomous sustainable production programmes. In terms of international intervention, then, the challenge may be expressed as the need to "broaden from a "welfarist" focus to incorporate -and emphasize- the active role of women's agency. No longer the passive recipients of welfareenhancing help, women are increasingly seen, by men as well as women, as active agents of change: the dynamic promoters of social transformations that can alter the lives of both women and men (Sen, 1999:189).

Focusing on the situation of Sahrawi women and their contribution to the process of Local Human Development in the camps, we argue that women have been key active players in the enlargement of Sahrawi refugees' capabilities. In particular, it is crucial to underline their capacity building efforts and leadership in sectors such as education and training, health, camp management and logistics, production, food distribution, and justice and social affairs. Sahrawi women, organized around the NUSW, have played a leading role in their community's development rarely reached in other protracted refugee situations. This experience reflects the appropriateness of a notion of capacity enlargement which recognizes the centrality of the 
collective dimension in human development (Morgan, 2006). This collective dimension is particularly relevant in reference to women's agency, which tends to prioritise the search for collective responses to common problems instead of individualised solutions.

However, Sahrawi women have not only helped improving and developing the capacities of the refugee population as a whole, but they have also worked on their own individual and collective empowerment. This process was facilitated by the prevalence of an Arab-Berber tradition that had historically valued and respected Sahrawi women's autonomy and socio-economic influence. In this case, the importance of the traditional dimension shows the need for a greater knowledge and understanding of cultural and anthropology aspects on the part of humanitarian and development international actors (Voutira \& Harrell-Bond, 1995), particularly for a better promotion of developmental value within the camps.

Added to cultural aspects, the outbreak of the conflict was a main determinant of the position of women in the Sahrawi society over the past three decades. As a consequence of the conflict, the assumption of important social and community responsibilities by women has been accompanied by political and public recognition of their role. At the same time, this has allowed for the development in the refugee camps of a well-organized women's movement with the capacity to raise gender claims to the power structures ${ }^{\mathrm{XIX}}$. Linked to Rowlands' (1995) notion of empowerment, Sahrawi women not only gained access to decision-making spaces in the camps, but also entered into a process of increasingly perceive themselves as capacitated and legitimated to occupy those spaces. To this purpose, the NUSW has situated at the core of its policy strategy the importance of education and training measures directed to women (VIDC, 2006).

Despite their achievements, women also face important limitations which have made their daily struggle really difficult. In the first place, the conflict charged them with the responsibility to address new and urgent challenges in a hostile environment and with very scant resources. Besides, Sahrawi women faced the task of restructuring family and social life in the camps, assuming the loss of their relatives (parents, children, husbands, brothers) and undertaking nation-building without time or space for the socialization of mourning. Their contribution to local development in the camps, then, has not only been directed to the increase of material resources for refugees but also to the reconstruction and maintenance of family and social ties, which has turned to be fundamental in order to cope collectively in such extreme conditions of permanent refugee. As it is integrated in Sen's capability approach, this social resilience becomes a central component of both human agency and empowerment (Sen, 1999).

Another limitation faced by Sahrawi women is that there are certain public spaces in which their participation has been more restricted, such as the government bodies of the SADR and the POLISARIO Front ${ }^{\mathrm{xx}}$. In particular, it is striking their limited presence in the area of Sahrawi Foreign Policy. Despite the outstanding projection of the NUSW in several international forums and women's networks, there are still few women in the foreign policy section of the POLISARIO Front, and hardy ever we find a woman ambassador or delegated to regional governments. The training of new generations of women with university degrees and language 
skills is contributing to reverse this situation and increase the number of women in those spaces. In fact, for women, the enlargement of their educational capacities is at the core of the empowerment process, which they link to the notion of "power to", that is, the authority to make decisions, as well as the capacity to manage and resolve problems (Oxaal \& Baden, 1997).

However, occupying more political decision-making spaces clearly remains a challenge for Sahrawi women's movement. Related to the difficulties women encounter to enter certain positions in their society, a major and growing concern for them is the extent to which their present roles, responsibilities and rights will be respected in the future. Actually, after the cease-fire in 1991, the military confrontations started to fall and men spent longer periods of time in the camps. With their return to the camps, men's presence in decision-making bodies progressively increased and the conflict over the scarce economic and social resources is becoming more evident now in gender terms.

Sahrawi women are conscious of the experience of other women in countries affected by conflict and emergency, in which any chance for a gender transformation towards a more equitable relationship between women and men disappeared as soon as the armed conflict ended. Women in the camps are now fulfilling crucial roles as teachers, doctors and nurses, administrators, managers and participants in daily social and political life that are beneficial not only to them but to the whole society. Thus, the variety of coping strategies developed by women go far beyond what is needed for survival, as they have become over the decades crucial stakeholders of local development initiatives in the camps. The consequence, then, is that women are not to be considered just as "helpless victims" or a "vulnerable group", as they frequently are in humanitarian and development discourses (Juliano, 1998), but active subjects in their refugee community's recovery and development, and thus fundamental agents to be promoted and supported.

Even if the POLISARIO Front was from the start of the national liberation struggle a driver of training and participation for women, the question that finally arises is whether this decision was taken on the basis of the short-term needs or whether it was part of a sincere bid for a more egalitarian society. In any case, Sahrawi women do not seem willing to hand over their rights and accept a reversal of their actual position in society, neither during their stay in refuge nor in a future return to the Western Sahara territory. Much on the contrary, above all they maintain a strong will to hold on to their so costly gained social, economic and political achievements. 


\section{References}

ACORD. 1995. Development in Conflict. The experience of ACORD in Uganda, Sudan, Mali and Angola. London: Overseas Development Institute, Relief and Rehabilitation Network.

AECID. 2005. Población Saharaui. Available at: http://www.maec.es/SiteCollectionDocuments/ Cooperaci\%C3\%B3n\%20espa\%C3\%B1ola/Publicaciones/DEP_saharaui.pdf Date of access: 24 November 2009

ALSOP, R. and KUREY, B. 2005. Local Organizations in Decentralized Development: Their Functions and Performance in India. World Bank.

ANDERSON, M.B. and WOODROW, P.J. 1989. Rising from the Ashes. Development Strategies in Times of Disaster. Boulder: Westview Press.

BAKEWELL, O. 2002. Refugee Aid and Protection: Working in Parallel or Cross-purposes? New Issues in Refugee Research, Working Paper No. 35. Geneva: UNHCR.

BYRNE, B. and BADEN, S. 1995. Gender, Emergencies and Humanitarian Assistance. Bridge Report. Brighton: Institute of Development Studies.

CAVAGLIERI, S. 2005. Livelihoods \& Micro-finance in Refugee Camps. Available at: http://www. gdrc.org/icm/disasters/Livelihoods.pdf Date of access: 30 December 2008

CISTERO, J. and FREIXES, T. 1987. Sahara. Una lección de historia. Barcelona: Altagraf.

CLARK, D. 2006. The Capability Approach: Its Development, Critiques and Recent Advances. Economic and Social Research Council (ESRC). Available at: http://www.gprg.org/pubs/workingpapers/pdfs/gprg-wps-032.pdf Date of access: 16 November 2008

DARA. 2009. Evaluation of DG ECHO's action in the Saharawi refugee camps, Tindouf, Algeria (2006-2008). Available at: http://www.daraint.org/nueva/img/noticias/ECHO_Sahara_report.pdf Date of access: 15 October 2009

EL MEHDI, F. 2006. Las casas de las mujeres facilitan nuestro empoderamiento. Interview in Jabetu, 2, January. Basauri (Spain).

FIREBRACE, J. 1992. The Sahrawi refugees: Lessons and prospects. (In Lawless, R. and Monahan, L. eds. War and Refugees: The Western Sahara Conflict. New York: Printer Publishers.)

FUKUDA-PARR, S. 2003. The Human Development Paradigm: Operationalizing Sen's ideas on capabilities. Feminist Economics, 9(2-3):301-317.

HARRELL-BOND, B.E. 1986. Imposing Aid. Emergency Assistance to Refugees. Oxford: Oxford University Press.

IASC. 2007. Gender and livelihoods in emergencies. (In Gender Handbook in Humanitarian Action. Inter-Agency Standing Committee. Available at: http://ochaonline.un.org/HumanitarianIssues/ GenderEquality/KeyDocuments/IASCGenderHandbook/tabid/1384/language/en-US/Default.aspx Date of access: 10 November 2008

IBAÑEZ, A. 2001. El Salvador: War and Untold Stories - Women Guerrillas. (In Moser, C. and Clark, C. eds. Victims, Perpetrators or Actors? Gender, Armed Conflict and Political Violence. London \& New York: Zed Books.)

JULIANO, D. 1998. La causa saharaui: Las mujeres siempre hemos sido muy libres. Barcelona: Ed. Icaria.

KABEER, N. 2001. Reflections on the measurement of women's empowerment, Discussing Women's 
Empowerment-Theory and Practice, Sida Studies, No. 3, Stockholm: Novum Grafiska.

KUTSCHERA, C. 1996. Algeria’s fighting women (interview). The Middle East, April.

LIPPERT, A. 1992. The Saharawi refugees: Origins and organization. (In Lawless, R. and Monahan, L. eds. War and Refugees: The Western Sahara Conflict. New York: Printer Publishers.)

MOORE, M. 1995. Promoting Good Government by Supporting Institutional Development. IDS Bulletin, Vol. 26. Brighton: International Development Studies.

MORGAN, P. 2006. The concept of Capacity. European Centre for Development Policy Management. http://info.worldbank.org/etools/docs/library/232261/Morgan\%20\%2D\%20Capacity\%20\%2D\%20 What\%20is\%20it\%2010052006.pdf Date of access: 10 November 2008

\section{ODI see OVERSEAS DEVELOPMENT INSTITUTE}

OVERSEAS DEVELOPMENT INSTITUTE. 2001. Supporting Livelihoods in Situation of Chronic Political Instability, Report of the Planning Workshop held on $12^{\text {th }}$ February at Avonmouth House, London.

OXAAL, Z. and BADEN, S. 1997. Gender and Empowerment. Bridge Report. Brighton: Institute of Development Studies

PÉREZ DE ARMIÑO, K. dir. 2001. Diccionario de acción humanitaria y cooperación al desarrollo. Barcelona: Icaria \& Bilbao: Hegoa.

ROWLANDS, J., 1995. Empowermet examined. Development in Practice, 5(2), May.

SCARCIA, B. 1992. Women in Western Sahara. (In Lawless, R. and Monahan, L. eds. War and Refugees: The Western Sahara Conflict. New York: Printer Publishers.

SEN, A. 1999. Development as Freedom, Oxford: Oxford University Press.

TURPIN, J. 1999. Women and War. (In Kurtz, L. ed. Encyclopedia of Violence, Peace and Conflict. Vol. 3. Academic Press. Austin, p. 801-811.)

\section{UN see UNITED NATIONS}

UNDP. 1990. Human Development Report. New York: Oxford University Press. Available at: http:// hdr.undp.org/en/reports/global/hdr1990 Date of access: 10 November 2008

UNDP. 2002. Report of the UN Inter-Agency. Workshop on Capacity Development, Geneva, 20-22 November. Available at: http://www.undg.org/archive_docs/6351-Report_of_the_UN_Inter-Agency_ Workshop_on_Capacity_Development_Geneva_20-22_November_2002.pdf Date of access: 10 November 2008

UNDP. 2007. Supporting Capacities for integrated Local Development. Available at: http://www.capacity.undp.org Date of access: 10 November 2008

UNITED NATIONS. 1960. Declaration on the Granting of Independence to Colonial Countries and Peoples, General Assembly Resolution A/15/1514. New York.

VÁZQUEZ, N. 1997. Mujeres-montaña. Vivencias de guerrilleras y colaboradoras del FMLN. Madrid: Ed. Horas y Horas.

VIDC. 2006. Género y conflictos armados: Sahara Occidental. Viena (Austria).

VOUTIRA, E. and HARRELL-BOND, B.E. 1995, In Search of the Locus of Trust: The Social World of the Refugee Camp. (In Daniel, K. and Knudesn, J. eds. (Mis)trusting Refugees, University of California Press.) 
WALLACE, T. 1994. Sahrawi women: Between ambition and suffering. Focus on Gender, 2(1), February.

UNHCR/WFP. 2006. Acute Malnutrition in Protracted Refugee Situations: A Global Strategy. Available at: http://www.refugees.org/uploadedFiles/Investigate/Anti_Warehousing/UN_Docs_\&_ Exchanges/WFP-UNHCR\%200601\%20Acute\%20Malnutrition\%20in\%20PRS\%20(w-emphasis). pdf Date of access: 5 November 2008

ZETTER, R. 1998. International Perspectives on Refugee Assistance. (In Ager, A. ed. Refugees: Contemporary Perspectives on the Experience of Forced Migration. Cassell (G.B.), p. 1-27.)

\section{Notes}

I. This work has been done in the framework of the Research Group on Human Security and Local Human Development of HEGOA-Institute of Development and International Cooperation Studies, at the University of the Basque Country (http://www.hegoa.ehu.es). The contents of this paper are part of an ongoing research which combines the examination of the selected bibliography with first hand information collected during field work in the Sahrawi refugee camps in Tindouf, Algeria $(2007,2008)$.

II. Following Oxaal and Baden (1997), power can operate in diverse ways: a) Power over: it implies a domination/subordination relation which is based on socially sanctioned threats of violence and intimation; b) Power to: it is linked to the authority to make decisions, as well as the capacity to manage and resolve problems; c) Power with: it implies the organization of people with a common purpose or to reach collective objectives; and d) Power within: it refers to self-confidence and individual consciousness and assertiveness; it is also linked to the capacity of individuals to recognize -through analysis- their own experience about how power operates in their lives, and to gain the confidence to act with the aim of influencing and changing this circumstance.

III. Livelihood has been defined as the "control that an individual, a family or any other social group has of an income and/or a set of resources that may be used or exchanged to satisfy their needs. This may range over information, cultural acknowledgment, social networks, legal rights as well as physical resources, such as land or tools" (Blaikie et all, cited in Pérez de Armiño, 2001: 584).

IV. The case of the Western Sahara has been defined as a clear example of protracted refuge by the United Nations High Commission for Refugees and the World Food Programme. See: Acute Malnutrition in Protracted Refugee Situations: A Global Strategy (WFP \& UNHCR, 2006).

V. The basic foundations for these agreements were: transfer of the Western Sahara administration to Morocco and Mauritania; Spain's departure from the territory on the agreed date; and respect for the Sahrawi people's will by means of the Yemaa or Parliament. It is important to specify that Spain transferred the administration of the territory but not its sovereignty. Western Sahara remains one of the non-autonomous United Nations territories; a Spanish colonial territory still to be decolonized.

VI. Administrative division or province named after the major cities on the Western Sahara.

VII. Camp communities or municipalities named after towns or cities of the Western Sahara.

VIII. Between 1980 and 1987 Morocco built in the Western Sahara territory a large defensive wall known as the Berm, which was mined and reinforced with barbed wire, observation posts and sophisticated alarm systems. The Berm enclosed the entire population of the main Western Saharan centres, as well as the territory's rich phosphate deposits. In the West side of the wall, the occupied territory remained under Moroccan domain after the defensive wall was built, and the liberated territories are those managed by the POLISARIO Front, which lie to the East of the wall.

IX. Cuts in the mount of Humanitarian Assistance were recognized by the United Nations High Commissioner for Refugees, Antonio Guterres, during his visit to the refugee camps in September 2009. (See official website of UNHCR: www.unhcr.org). 
X. In Argelia, for example, many women participated actively in the National Liberation Front (FLN) during the independence war on France. However, once independence was achieved, they suffered a regression in their situation due to political, social and religious pressures. They were forced back into their traditional roles prior to the nationalist revolution; they were excluded from the public space and promises such as the massive schooling for girls and women's right to work and to perceive an equal salary in the same conditions as men were never become a reality. Many women experienced this postconflict regression as a betrayal on the part of the Algerian liberation movement (Kutschera, 1996).

XI. The concept of matrilineality shows a way of adscription to the linage which is especially favourable to women: ethnic ownership is assigned to the family of the mother, therefore control over women's sexuality that is typical of patrilineal societies lose all its sense. The matrilocality implies that just married couples go living with the wife's family, or at least nearby, which implies that she can count on the support of her family group and thus the husband's power over her declines.

XII. Given that many of the men were fighting, at the time women in the camps comprised an estimated 80 per cent of the adult population (Firebrace, 1992: 181).

XIII. There is not an official census about the refugee population in Tindouf, thus different agencies offer their own and disparate estimates. While the UNCHR and WFP recognise a number of 116.530 refugees (2009), other sources such as the CIA's World Factbook rise the number of estimated refugees as to 405.210 (including soldiers and nomads living in the so called "liberated territories").

XIV. Typical Sahrawi dress.

XV. The region of the Argelian Hammada in Tindouf may be one of the least hospitable places in the world. The harsh climate and desert, with daytime temperatures that can reach $60^{\circ} \mathrm{C}$ in the summer and gusts of the sirocco with speeds of almost 100 kilometres per hour cause dusty and dry conditions that disrupt normal life very often. The enormous variation in temperature between night and day conditions the type and amount of food and water people need to survive. (For an extended description of life conditions in the Hammada, see Firebrace, 1992).

XVI. Rabuni is the core operation centre of the SADR. It is located approximately 20 kilometres from the camps and is headquarter for all the different ministries. In this centre were built both the National Hospital, which has more technical and professional resources than the rest of the hospitals in the wilayas, and the Military Hospital for those wounded during the war.

XVII. This programme allows Sahrawi children spending summer time outside the harsh living conditions of the refugee camps. During three months these children are hosted by families, mainly in Spain and Italy.

XVIII. The need for greater aid coordination is one of the main conclusions of the evaluation report prepared for ECHO by DARA International (DARA, 2009). The same is also stated in the Country Strategy document of the Spanish Agency of Development Cooperation (AECID, 2005).

XIX. One of the major achievements of the NUWS has been the promotion of law reforms to protect women's rights. A notorious example is the Marriage Law, one of the most advanced in a Muslim society.

XX. The Saharawi Parliament ensures a participation of at least 30 per cent of women. Besides, there are two women ministers, and many other women in charges of responsibilities such as State Secretariats or rulers of the wilayas. 